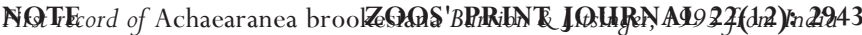

\section{FIRST SPECIMEN BASED RECORD OF THE EGYPTIAN FREE-TAILED BAT TADARIDA AEGYPTIACA E. GEOFFROY, 1818 (CHIROPTERA: MOLOSSIDAE) FROM ANDHRA PRADESH, INDIA}

\section{Bhargavi Srinivasulu ${ }^{1}$ and C. Srinivasulu ${ }^{2}$}

\author{
1,2 Wildlife Biology Section, Department of Zoology, \\ Osmania University, Hyderabad, Andhra Pradesh 500007, India \\ Email: ${ }^{2}$ hyd2masawa@gmail.com
}

plus web supplement of 1 page

\begin{abstract}
Abbreviations
BB - Braincase breadth; C-M $\mathrm{M}^{\mathrm{n}}$ - Maxillary toothrow; C-M - Mandibular toothrow; $\mathrm{C}^{1}-\mathrm{C}^{1}$ - Anterior palatal width; $\mathrm{CBL}$ - Condylo-basal length; CCL - Condylo-canine length; E - Ear; FA - Forearm; GTL - Greatest length of skull; $\mathrm{M}$ - Mandible length; $\mathrm{M}^{1}-\mathrm{M}^{1}$ - Posterior palatal width; T - Tail length; Tib - Tibial length; ZB - Zygomatic breadth
\end{abstract}

Chakraborty et al. (2004) reported the presence of Egyptian Free-tailed Bat (Tadarida aegyptiaca E. Geoffroy, 1818) in Andhra Pradesh based on sightings by Nagulu et al. (1998). It has been reported from Adilabad, Guntur, Khammam, Karimnagar, Kurnool, Mahbubnagar, Nalgonda, Prakasam, Ranga Reddy and Warangal districts of Andhra Pradesh (Nagulu et al., 1998; C. Srinivasulu, pers. obser.). There has been no collections of this species from Andhra Pradesh (see Chakraborty et al., 2004), hence we report the first collection locality record of Egyptian Free-tailed Bat from the state.

The Egyptian Free-tailed Bat is distributed through most of Africa, Egypt, Saudi Arabia, Yemen, Oman to India and Sri Lanka. In India, this species has been recorded from Rajasthan, Gujarat, Madhya Pradesh, Maharastra, Karnataka, Kerala, Tamil Nadu and West Bengal (Simmons, 2005; Pradhan \& Mahabal, 2001; Karad \& Yardi, 2004; Bates \& Harrison, 1997; Srinivasulu et al., in press).

During a survey, in March 2000, to document the faunal elements of the Osmania University Campus, Hyderabad, we came across an all-male colony of seven individuals of $T$. aegyptiaca under the banner board on the east-facing wall of the Arts College building at about $1100 \mathrm{hr}$. This species is known to roost in caves and buildings (Rosevear, 1965; Kashyap, 1978), under stone slabs on hillsides (Wroughton, 1912; Irwin \& Donnelly, 1962; Phillips, 1980), under banner boards (Freeman, 1981; Pradhan \& Mahabal, 2001), and narrow cracks and spaces in pillars (Roberts, 1977; Brosset, 1962).

One individual was collected with the help of a scoop net from the roosting site. The voucher specimen was identified based on available literature, standard keys and character matrices (Bates \& Harrison, 1997; Srinivasulu, 2003). Morphometric and cranial measurements were recorded and the specimen (NHMOU/Chir/OU/1) was preserved in $70 \%$ alcohol and deposited in the Natural History Museum at the Department of Zoology, Osmania University.
Description of the voucher specimen M. Ganeshkumar \& M. Siliwal

Morphology: This is a medium sized free-tailed bat (FA: $49.0 \mathrm{~mm}$; T: $36.35 \mathrm{~mm}$; E: $19.30 \mathrm{~mm}$; Tib: $15.59 \mathrm{~mm})$. The tail projects well beyond the posterior border of the uropatagium. Ears are large, not joined on the forehead, well separated. The feet are hairy, wing membranes hairless. Pelage is fine and dense and the coat colour is dark chestnut brown dorsally and paler ventrally.

Cranial measurements (mm): (Images $1^{\mathrm{w}} \& 2^{\mathrm{w}}$ ) GTL: 19.76; CBL: 18.86; CCL: 17.93; C-M ${ }^{3}: 7.29 ; \mathrm{C}^{1}-\mathrm{C}^{1}: 5.09 ; \mathrm{M}^{1}-\mathrm{M}^{1}$ : 8.26; M: 14.00; C-M : 8.25; ZB: 11.78 ; BB: 9.98 .

Dentition: The upper premolar is small and is in the toothrow and there are two pairs of lower incisors.

\section{REFERENCES}

Bates, P.J.J. \& D.L. Harrison (1997). Bats of the Indian Subcontinent. Harrison Zoological Museum, England, xvi + 258pp.

Brosset, A. (1962). The bats of the central and western India. Part II. Journal of the Bombay Natural History Society 59: 707-746.

Chakraborty, S., T.P. Bhattacharya, J.K. De, M.K. Ghosh, T.K. Chakraborty \& A.K. Poddar (2004). Mammals. In: Director (ed.), Fauna of Andhra Pradesh Part 2. State Fauna Series 5, 96 pp.

Freeman, P.W. (1981). A multivariate study of the family Molossidae (Mammalia: Chiroptera): morphology, ecology, evolution. Fieldiana Zoology New Series 7: viii $+173 p p$.

Irwin, M.P.S. \& B. Donnelly (1962). On bats collected from Limpopo River... II. A general description of the area with notes on habitat and ecology. Occasional Paper of the National Museum of S. Rhodesia 26B: 767-769.

Kashyap, S.K. (1978). Occurrence and observations on Tadarida aegyptiaca (E. Geoffroy, 1818) (Molossidae: Chiroptera), the wrinkle-lipped bat in East Nimar district, Madhya Pradesh (India). Journal of the Bombay Natural History Society 75(3): 917-918.

Korad, V.S. \& K.D. Yardi (2004). Ecological study and faunistic survey of bats from Pune Corporation limits, Maharashtra State, India. Records Zoological Survey of India 102(1\&2): 115-136.

Nagulu, V., V.V. Rao \& C. Srinivasulu (1998). Biodiversity of select habitats in Eastern Ghat regions of Andhra Pradesh. Proceedings of the National Seminar on Conservation of Eastern Ghats. 24-26 March, 1998. EPTRI, Hyderabad and Andhra University, Waltair, Andhra Pradesh, 6-35pp.

Phillips, W.W.A. (1980). Manual of the mammals of Sri Lanka. Part I. Wildlife \& Nature Protection Society of Sri Lanka, 116pp.

Pradhan, M.S. \& A. Mahabal (2001). Observations on the roosting site of freetailed bat Tadarida egyptiaca (E. Geoffroy) in Pune. BatNet CCINSA Nerwsletter 2(1): 15 .

Roberts, T.J. (1977). The Mammals of Pakistan. Ernest Benn Ltd., London \& Tonbridge, $361 \mathrm{pp}$.

Rosevear, D.R. (1965). The Bats of West Africa. British Museum (Nat. Hist.), London, ixvii + 481pp.

Simmons, N.B. (2005). Chiroptera, pp.312-529. In: Wilson, D.E. \& D.M. Reeder (eds). Mammals Species of the World: A Taxonomic and Geographic Reference. $3^{\text {rd }}$ ed. Vol. 1. The John Hopkins University Press, Baltimore, xxxv + 2142pp.

Srinivasulu, C. (2003). Key to the Bats of South Asia., 107 pp. (unpublished) Srinivasulu, C., B. Srinivasulu \& Y.P. Sinha (in press). Checklist of Bats (Mammalia: Chiroptera) of South Asia. Journal of Threatened Taxa

Wroughton, R.C. (1912). Report No. 4: Nimar (844-851). Bombay Natural History Society's Mammal Survey of India. Journal of the Bombay Natural History Society 21(3): 820-851

\section{Acknowledgements}

We thank the Head, Department of Zoology for encouragement and necessary facilities. We acknowledge individual research grants from CSIR, New Delhi.

${ }^{\mathrm{w}}$ See Images in the web supplement at www.zoosprint.org

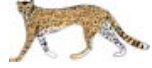

Manuscript 1834; (C) ZOO; Date of publication 21 November 2007 Received 08 August 2007; Revised received 25 October 2007; Finally accepted 10 November 2007 